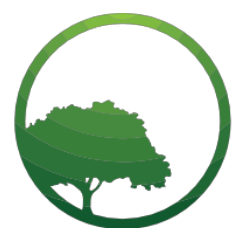

Business \& Social Science IJRBS

\section{Research in Business and Social Science}

IJRBS Vol 7 No 4, ISSN: 2147-4478

Contents available at www.ssbfnet.com/ojs

\title{
Organizational Culture, Communication and Leadership Style on Job Satisfaction
}

\section{Anak Agung Ngurah Gede Sadiartha}

\author{
Lecturer of Economic Faculty, University of Hindu Indonesia (UNHI) Denpasar
}

\section{Sunday Ade Sitorus}

Lecturer at the Department of Management, STIE ITMI, Medan

\begin{abstract}
This research aims to investigate the effect of the role of organizational culture, communication and leadership style on job satisfaction. The object of this research is Senior High Schools (SMA)/Vocational Secondary School (SMK)/MAN, while the subject is 55 School Principals. Four variables from the research data were gathered through instruments in the form valid and reliable questionnaires. Statistical Analysis of the research data used multiple linear regression analysis with the significance in accordance with the output of SPSS 22.0. Findings indicated that organizational culture has an effect but not significant on job satisfaction, while communication has a significant effect on job satisfaction, and leadership style has a significant effect on job satisfaction, variable of organizational culture, communication and leadership style has a significant effect on job satisfaction.
\end{abstract}

Key words: Organizational Culture, Communication, Leadership Style, Job Satisfaction

JEL classification: $015, P 36$

Submitted: 14.10.2018 - Accepted: 11.11.2018

\section{Introduction}

Organizations are established for the purpose of achieving a particular goal. An organizational goal can be achieved through good performance from the entire human resources within an organization. The factor that can turn an organizational culture into school principal effective work is by changing the previous organization culture which is poor and not in accordance with the values of the new organization culture or better on all the leadership of sschool institutions/organizations, staffs, volunteer teachers, participative and independent. Today, many leaders and their subordinates in an institution/school is very difficult to be an example, change themselves, and ignore the values and culture of the school organization/institutions. Quality education improvement is aimed for all levels of education. A real quality improvement can be seen through the physical and non-physical developments. Physical development can be seen through construction of a building and its equipment, while non-physical development can be seen through the curriculum, vision and mission of a school and its programs. Lately attempts have been made to develop the schools as government increased 
education funding by $20 \%$. This development is performed by a leader in carrying out the activities as he is mandated as the head of school management. In reality, it has been found out that a great number of school principals could not set as examples as a role model that should be modelled and imitated by his subordinates so as to give an impact on work motivation that can be performed effectively. An organizational culture is the values or norms that bind an individual in carrying out the tasks in an organization. It is clear that a good organizational culture may affect communication and leadership style on good job satisfaction by subordinates, students and the surrounding environment. A smooth communication also forms a binding force between employees and teachers at schools. The behavior of a leader is the limelight from outside as well as inside an organization.

The Image of a leadership is a reflection in which all employees and the community pay attention to what is called by the term "imaging", where this imaging will build trust to subordinates or to the wider community. This as proved by some cases where in performing their tasks and functions, the leaders failed to comply with the rules and moral values of a nation that can cause the image of an organization bad. Leadership style is a style, attitudes and behavior of a person to deal with others which are formed by his educators and experiences as well as by interaction with the environment. It is clear that the leadership style can influence organizational culture that affect the environment, one's physical, and situation through education transferred through certain values. (Hofstede, Hofstede, \& Minkov, 2010), Leadership style can influence empathy, as with an attitude, we can understand others. And leadership styles can affect individual work motivation and his subordinates, as it can positively increase psychological condition of his subordinates. Dissatisfaction in service given by school principal may result in a great number of complaints from the services recipients delivered through various ways whether directly or indirectly. School employees tend to have problems with their punctuality, including leaving for hours, break time and leaving from work. At times, it takes forever for the public to wait for the school staff to serve them for their document business. This indicates that unmanaged leadership, motivation, communication and job satisfaction between superior and subordinates result in a bad impact on the services.

\section{Literature Review}

\section{An Organizational Culture}

An organizational culture is a working method based on a system of values held by every staff or employees in an organization. An organizational culture is also determined by a system, procedures and the organizational structure itself. The word "culture" itself is derived from the Sanskrit word "budhayah" the plural of buddhi or mind and its plural word is budi-daya, which literally means "daya" from "budi", or in other words "culture is the power of wisdom in the form of reasoning, feeling and desire. While "culture" is the development of a culture itself as a result of reasoning, feeling and desire. According to (S. T. Robbins, Judge, \& Hasham, 2009), there are seven characteristics of an organizational culture:

- Innovation and risk taking. All this while, employees have been encouraged to be innovative and dare to take the rial.

- Attention to detail. How far employees are able to show their alertness, analytical skills and attention to detail

- Results-oriented

- People-oriented

- Team-oriented

- Agressiveness

- Stability.

\section{Communication}

Communication is defined as a transition or information transition and understanding using symbols together from one person or group to another party and those symbols can be either verbal or nonverbal (Ivancevich \& Matteson, 1980). Judge (S. Robbins \& Judge, 2009) redefined communication as a relationship or interaction between superiors and subordinates (downward communication) or from the subordinates to 
superiors (upward communication) or among fellow workers (horizontal communication) and or communication across channel in order to achieve organizational or individual goal. (Muharto, 2014), Communication in an organization consists of instructions, reports, questions and petition. (Hofstede et al., 2010), argues that an inter-personal communication can be effective if consists of five things, namely openness, empathy (feeling what others feel), support (agreeing), positivity and similarities. The indicators of communication include:

- Togetherness within a school/Organization.

- Trust to transfer values.

- Discipline to implement

- Imposing sanctions for those violating the rules, values, norms.

- Working spirit as a form of practicing the culture.

\section{Leadership Style}

An organizational goal is achieved through the effectiveness of leadership where it directs the whole company resources to the maximum. The role of a leader in managing the members of an organization is an important factor which can determine the end form of an organization as well as behaviors of its members. House puts together leadership by recommending that an effective leadership has domination, selfconfidence, effect and displays high morality to increase the level of charismatics (Ivancevich \& Matteson, 1980). Fry in (Rousseau, 1997) puts forth that leadership is an effort extrinsically or intrinsically motivates their followers to simultaneously achieve personal and organizational goals through the achievement of suitability or congruents between subordinates and tasks and increase the reward of the followers. Mitchell (House \& Mitchell, 2007) proposed four types of leadership:

- Directive leadership

- Supporting leadership

- Participatory leadership, and

- Achievement-oriented leadership.

A principal leadership style is the behavior of school principal in leading, directing, nurturing and influencing subordinates in learning activities at school. Based on that, then the dimension of leadership style of a school principal in this research is open, dominating the implementation of the task and situational.

\section{Job Satisfaction}

Job satisfaction is a pleasant or unpleasant emotional state where the employees see their Works (Kosteas, 2011). Job satisfaction reflects the feelings of a person towards work and everything he faces within workplace. (de Graaf-Zijl, 2012) stated that job satisfaction is the supporting or unsupporting feelings experienced by employees in the workplace. With high salary, job satisfaction is not Guarantee (Mihalcea, 2014). According do Kaplan and Norton (Kaplan \& Norton, 1996), there are six elements of customer satisfaction:

- Involvement with decisions

- Recognition for doing a good Bob

- Access to sufficient information to do the job well,

- Active encouragement to be creative and use innitiative

- Support level from staff functions

- Overall satisfaction with company.

Satisfaction does not necessarily lead to high productivity, as stated cy cascio (Cascio, 2010), that job satisfaction does not appear to be highly correlated with job productivity as such. In other words, high job satifaction does not always result in high productivity, not does low job satisfaction always result in low productivity. Obviously naviable other than job satisfaction or dissatisfaction can and do affect an employees job productivity. (Snell \& Bohlander, 2011), employees' job satisfaction may be indicated by several Tractors, such as: 
- Satisfaction with the preferred bor

- Satisfaction with the work rules system

- Satisfaction with colleagues as elements of environment/workplace.

- Job satisfaction as an element of the relationship between subordinates and superiors since in practice most of the tasks are given by the superior

- Satisfaction with facilities provided

\section{Research and Methodology}

The subject in this research are school principals of high school in Siantar City. The population in this research are 71 Principals (pre survey) in Siantar City. The number of samples was determined using the following Slovin's formula :

$$
\begin{aligned}
\mathrm{n} & =\mathrm{N} /(1+\mathrm{Ne} 2) \\
& =55 \text { Principals }
\end{aligned}
$$

Where :

$\mathrm{n}=$ total samples

$\mathrm{N}=$ total population

e = error tolerance limit (5\%)

The calculation using the above formula resulted in 55 samples. The sampliong technique used simple random sampling.

\section{Data Analysis Technique}

The model of data analysis in this research is as follows :

$$
Y=a+b_{1} X_{1}+b_{2} X_{2}+b_{3} X_{3} e
$$

Where :

$Y=$ Variable of job satisfaction

$a=$ Constanta

b1, b2,b3 = Regression Coefficient

$\mathrm{X} 1=$ Variable of Organizational Culture

$\mathrm{X} 2=$ Variable of Communication X3 $=$ Variable of Leadership Style

$\mathrm{e}=$ Standard Error (error rate) $5 \%$

There are 7 (seven) assumption test for this research results.

- Normality Test

- Multicollinearity Test

- Heteroscedasticity Test

- Hypothesis Test

- Simultaneous Hypothesis Test (F)

- Partial Hypothesis Test (Test-t)

- Coefficient of Determination 


\section{Result and Discussion}

\section{Normality}

Below is the result of normality test using Kolmogorov-Smirnov from the variables of culture, communication, leadership style and job satisfaction:

Table 1: Normality Test

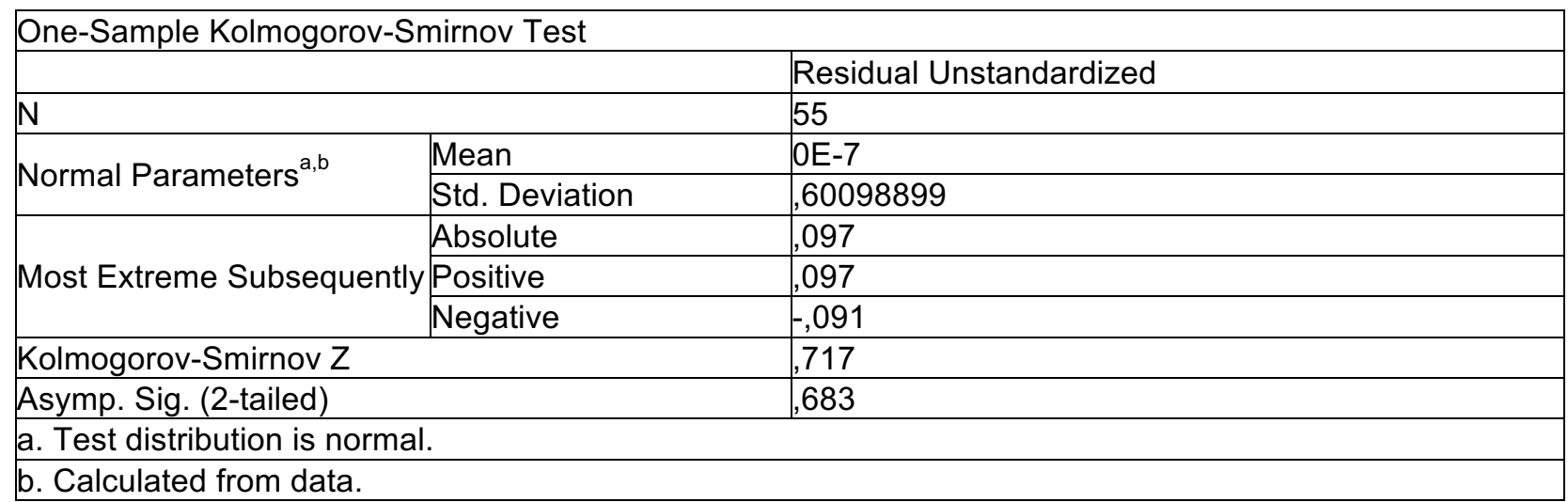

Based on the data on the table above, the variable of communication, an organizational culture and job satisfaction have the value of Sig. $=0,683>0.05$ thus declared as normally distributed. Other data normality test in this research used histogram and graphics (Normal P-P Plots).

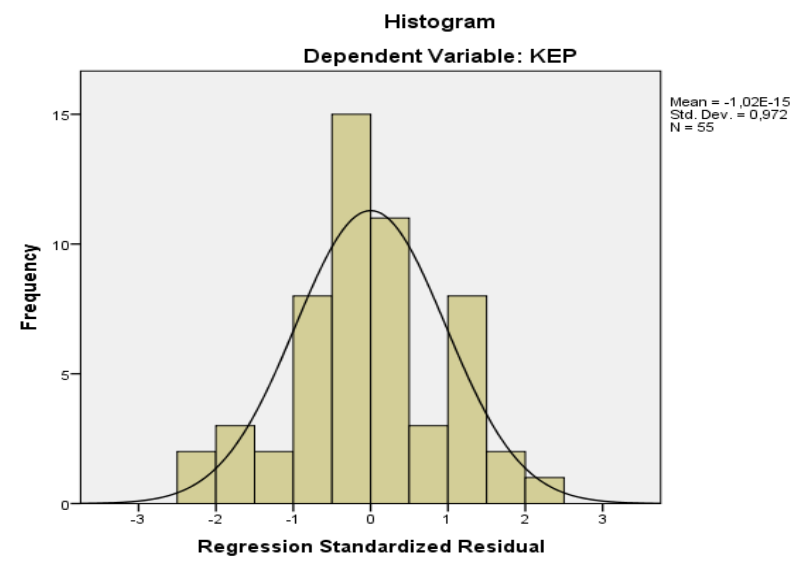

Figure 1: Histogram

Based on the image of the results of the above SPSS output, histogram diagram formed rounded normal curve and thus the residual is declared normal and normality assumption is met

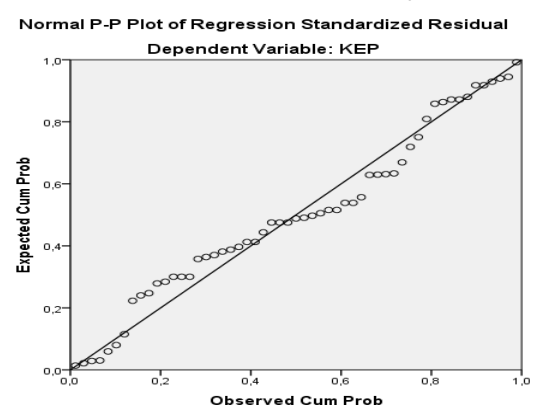

Figure 2: Normal P-P Plots 
From the above figure, it can be seen that the points or data are unidirectional and follow the diagonal lines. This can be concluded that the data are normally distributed.

\section{Multicollinearity Test}

The results of data processing from multicollinearity test is presented in the following table:

Table 2: Multicollinearity Test

\begin{tabular}{|l|l|l|l|l|}
\hline Correlations & \multicolumn{3}{l|}{ Collinearity Statistics } \\
\hline The Zero-order & Partial & Part 5 & Tolerance & VIF \\
\hline & & & & \\
\hline 533 &, 181 &, 044 &, 715 & 1.399 \\
\hline, 826 &, 685 &, 224 &, 476 & 2.101 \\
\hline 937 &, 901 &, 496 &, 516 & 1.937 \\
\hline
\end{tabular}

The above table shows that no the tolerance value under $10 \%$ and the value of Variance Inflation Factor (VIF) is no more than 10, which indicates that this regression model of these variables shows no multicollinearity problems.

\section{Heteroscedasticity Test}

How to predict heteroscedasticity in a model can be seen using Scatterplot pattern below :

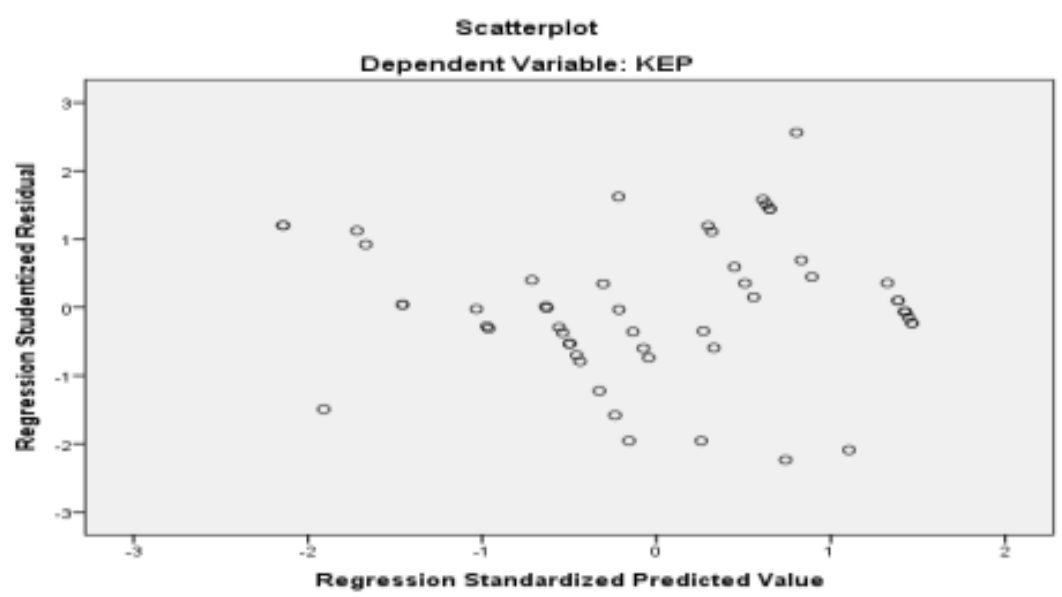

Figure 3: Heteroscedasticity test.

From the above figure, it is seen that the points are spread at random and spread out above or under 0 on the $Y$ axis. It is concluded that heteroscedasticity does not occur in a regression model leaving the regression model feasible to predict job satisfaction based on variable of cultural organization and employee satisfaction.

\section{T-test (Partial)}

The t-test used to test whether there is a significant impact between independent variables and dependent variables separately. The first hypothesis obtained the value of $t_{\text {count }}(1,317)<t_{\text {table }}(2,007584)$ and the significance value (SIG) of $0,194>0.05$, which lead to the conclusion that an organizational culture has an effect but not significant on job satisfaction. The second hypothesis obtained the value of $t_{\text {count }}(6,722)>t_{\text {table }}$ $(2,007584)$ and the significance value $(S I G)$ of $0,000<0.05$, which lead to the conclusion that communication has a significant effect on job satisfaction. The third hypothesis obtained the value of $t_{\text {count }}(14,873)>t_{\text {table }}$ $(2,007584)$ and the significance value (SIG) of $0,000<0.05$, which lead to the conclusion that has a significant effect on job satisfaction. 
Table 3: T-test Coefficients

\begin{tabular}{|l|l|l|l|}
\hline \multicolumn{2}{|c|}{ Model } & & \\
\hline \multirow{3}{*}{1} & T & Sig. \\
\hline & (Constant) &, 718 &, 476 \\
\cline { 2 - 4 } & BO & 1.317 &, 194 \\
\cline { 2 - 4 } & KM & 6.722 &, 000 \\
\cline { 2 - 4 } & GK & 14.873 &, 000 \\
\hline
\end{tabular}

Note: Dependent Variables: kept

\section{F Test (Simultaneous)}

Below are the results of hypothesis tests simultaneously from the variables in this research:

Table 4: F Test

\begin{tabular}{|c|c|c|c|c|c|c|}
\hline \multicolumn{7}{|c|}{ ANOVA $^{a}$} \\
\hline \multicolumn{2}{|c|}{ Model } & Sum of $S$ & & Mean Square & $\mathrm{F}$ & Sig. \\
\hline \multirow{3}{*}{1} & Regression & 324.132 & 3 & 108.044 & 282.517 & $000^{6}$ \\
\hline & Residual & 19.504 & 51 & 382 & & \\
\hline & Total & 343.636 & 54 & & & \\
\hline \multicolumn{7}{|c|}{ a. Dependent variables: KEP } \\
\hline
\end{tabular}

The total of $F_{\text {Table }}$ in this research is as follows: $F_{\text {table }}$ in accordance with $F$ Table is 2,786229 . The above table shows that the value of $F_{\text {count }}$ is 282,517 with probability 0,000 . Since its probability is smaller than 0.05 and $F_{\text {count }}(282,517)>F_{\text {table }}(2,786229)$ then $\mathrm{Ho}$ is rejected or $\mathrm{Ha}$ is accepted which means that variables of culture, communication, leadership style have a significant effect on on job satisfaction.

\section{Multiple Linear Regression Analysis}

Below is the table of the results of the processed

Table 5: Multiple Linear Regression Test Results Coefficients

\begin{tabular}{|l|l|l|l|l|}
\hline \multirow{2}{*}{\begin{tabular}{l} 
Model \\
\cline { 3 - 4 }
\end{tabular}} & $\begin{array}{l}\text { Unstandardized } \\
\text { Coefficients }\end{array}$ & $\begin{array}{l}\text { Standardized } \\
\text { Coefficients }\end{array}$ \\
\cline { 3 - 5 } & B & Std. Error & Beta \\
\hline 1 & (Constant) &, 678 &, 945 &, 052 \\
\cline { 2 - 4 } & BO &, 049 &, 037 &, 325 \\
\cline { 2 - 4 } & KM &, 320 &, 048 &, 691 \\
\cline { 2 - 4 } & GK &, 990 &, 067 & \\
\hline
\end{tabular}

Note: Dependent Variables: Kep

Data for multiple linear regression test of these variables: The regression equation formed from the data on the above table is as follows:

$Y=0,678-0,049 X_{1}+X 2+0,9900,320 X_{3}+e$

The above equation leads to the following results:

- Constanta $(a)=0,678$ which means that although the independent variable $\left(X_{1}\right)$; organizational culture and independent variable $X_{2}$, : communication and the independent variable $X_{3}$ : leadership style are 0 , then customer decision $(Y)$ remains to be 0,678

- Coefficient $X_{1}\left(b_{1}\right)=0.049$ and positive value. This means that each organizational culture variable improvement by 1 leads to the increased job satisfaction $(Y)$ by 0.049 . 
Sediartha \& Sitorus / International Journal of Research in Business and Social Science,

Vol 7 No 4, 2018 ISSN: 2147-4486

- Coefficient $X_{2}\left(b_{2}\right)=0,320$ and positive value. This means that each communication variable improvement by 1 leads to the increased job satisfaction $(Y)$ by 0,320

- Coefficient $X_{3}\left(b_{3}\right)=0.990$ and positive value. This means that each leadership style variable improvement by 1 leads to the increased job satisfaction $(Y)$ by 0,990

Based on the processed data above, it is revealed that the variable with the most dominant effect on job satisfaction is leadership style as its coefficient regression value is bigger than other independent variables.

\section{Coefficient of Determination}

Coefficient of Determination is obtained with the help of SPSS Program:

Table 6: Coefficient of Determination Coefficients

\begin{tabular}{|l|l|l|l|l|}
\hline Model & $R$ & R Square & $\begin{array}{l}\text { Adjusted } \\
\text { R Square }\end{array}$ & Std. Error of the Estimate \\
\hline 1 &, $971^{\mathrm{a}}$ &, 943 &, 940 &, 618 \\
\hline
\end{tabular}

Note: Dependent Variables: kept

The value of coefficient of determination (R Square) revealed that job satisfaction mutually influenced by an organizational culture, communication, leadership style by 0,940 or $94 \%$ while the remaining $16 \%$ is influenced by other factors beyond the scope of this research

Based on the data analysis previously mentioned, it is discovered that the variable of an organizational culture obtained the value of $t_{\text {count }}(1,317)<t_{\text {table }}(2,007584)$ and the significance value $(S I G) .0,194>0.05$ which lead to the conclusion that an organizational culture has an effect but insignificant on job satisfaction. The second hypothesis obtained the value of $t_{\text {count }}(6,722)>t_{\text {table }}(2,007584)$ and the significance value (SIG). $0,000<0.05$, which lead to the conclusion that communication has a significant effect on job satisfaction. The third hypothesis obtained the value of $t_{\text {count }}(14,873)>t_{\text {table }}(2,007584)$ and the significance value (SIG) of $0,000<0.05$ which lead to the conclusion that leadership style has a significant effect on job satisfaction. Meanwhile the value of $F_{\text {the table }}$ is in line with $F$ Table which is 2,786229 . The above table shows that the value of $F_{\text {count }}$ is 282,517 with probability of 0,000 . Since its probability is smaller than 0.05 and $F_{\text {count }}$ $(282,517)>F_{\text {table }}(2,786229)$ then $\mathrm{Ho}$ is rejected or $\mathrm{Ha}$ is accepted which means that the variables of culture, communication, leadership style have a significant effect on job satisfaction. The multiple linear regression equation formed is $Y=0,678-0,049 \times 1+0,320 \times 2+0,990 \times 3+e$. From this equation, it can be seen that the variable is a variable of leadership style as its coefficient regression is bigger than other independent variables. The extent of the influence can be seen from the coefficient of determination value. The value of coefficient of determination (R Square) showed that job satisfaction simultaneously influenced by organizational culture, communication, leadership style by $94 \%$ while the remaining $16 \%$ is influenced by other factors beyond the scope of this research. The results of the study showed that, simultaneously, an organizational culture, communication, leadership style have significant effects on job satisfaction of SMA/SMK/MAN principals across Siantar City and partially the variable of leadership style is more dominant than other two independent variables.

\section{Conclusions}

From the hypothesis result that carried out on the problem of study, it showed that:

a. Each organizational culture, Communication and Leadership style partially affected on job satisfaction

b. An organizational culture variable has an effect on on job satisfaction but insignificant. It's proved that there is no significant direct effect between organizational culture, it indicates that organizational culture in an organization or institution where the research is conducted, in the city of Medan, has not been able to significantly improve satisfaction at work. Thus, other variables should be sought in order to significantly improve job satisfaction at work. 
c. Communication has a significant effect influence on the on-job satisfaction. It indicates that Communication in an institution where the research is conducted, can significantly improve job satisfaction in their daily works.

d. Leadership style had a strong influence on the on-job satisfaction. It indicates that $d$. Leadership style in an organization or institution where the research is conducted can significantly improve job satisfaction in carrying out their daily duties.

e. Simultaneously, an organizational culture, communication, leadership style have significant effects on job satisfaction. . It indicates that organizational culture, communication, leadership style in an institution where the research is conducted, can significantly improve job satisfaction in their daily works.

\section{References}

Cascio, W. F. (2010). Managing Human Resources: Productivity, Quality of Work Life, Profits. Work, xxxi, 719. Retrieved from http://www.amazon.co.uk/Managing-Human-Resources-ProductivityQuality/dp/0072987324

de Graaf-Zijl, M. (2012). Job satisfaction and contingent employment. Economist, 160(2), 197-218. https://doi.org/10.1007/s10645-011-9180-7

Hofstede, G., Hofstede, G. J., \& Minkov, M. (2010). Cultures and Organizations: Software of the Mind, Third Edition. McGraw-Hill Education; 3rd edition. https://doi.org/10.2307/2393257

House, R. J., \& Mitchell, T. R. (2007). Path-goal theory of leadership. In Leadership: Understanding the dynamics of power and influence in organizations (2nd ed.). (pp. 241-254). https://doi.org/10.1177/014920639301900407

Ivancevich, J. M., \& Matteson, M. T. (1980). Optimizing human resources: A case for preventive health and stress management. Organizational Dynamics, 9(2), 5-25. https://doi.org/10.1016/00902616(80)90037-6

Kaplan, R. S., \& Norton, D. P. (1996). The Balanced Scorecard Translating Strategy In Action (Kaplan \& Norton, 1996, Harvard Business School Press).pdf. Proceedings of the IEEE. https://doi.org/10.1109/JPROC.1997.628729

Kosteas, V. D. (2011). Job satisfaction and promotions. Industrial Relations, 50(1), 174-194. https://doi.org/10.1111/j.1468-232X.2010.00630.x

Mihalcea, A. (2014). Leadership, Personality, Job Satisfaction and Job Performance. Procedia - Social and Behavioral Sciences, 127, 443-447. https://doi.org/10.1016/j.sbspro.2014.03.287

Muharto, T. (2014). Perilaku organisasi. In Tangerang Selatan: Universitas Terbuka (p. 6.38-40). https://doi.org/10.1017/CBO9781107415324.004

Robbins, S., \& Judge, T. (2009). Organizational Behaviour: Concepts, Controversies, Applications. Development.

Robbins, S. T., Judge, T. a, \& Hasham, E. S. (2009). Organizational Behavior. Pearson Education Limited.

Rousseau, D. M. (1997). Organizational Behavior in the New Organizational Era. Annu. Rev. Psychol, 48, 515-46. https://doi.org/10.1146/annurev.psych.48.1.515

Snell, S., \& Bohlander, G. (2011). Managing Human Resources. IEEE Engineering Management Review. https://doi.org/10.1109/EMR.2008.4490144 